\title{
Interictal hypermetabolic subcortical band on brain FDG-PET in doublecortin mutation
}

Figure 1 Brain MRI revealing subcortical band heterotopia
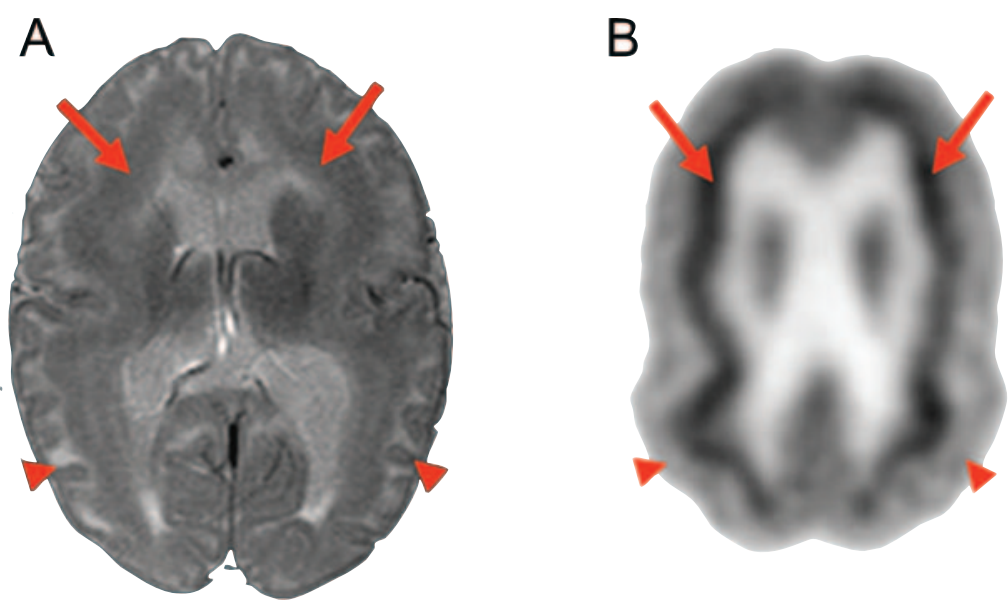

T2-weighted brain MRI (A) shows subcortical band heterotopia. Compared to basal ganglion on a $10 \%$ point color scale, FDG-PET (B) shows intensely increased FDG uptake (arrows) by the subcortical band and reduced uptake by the cerebral cortex (arrowheads).

Figure 2 Interictal scalp EEG with generalized slow spike and wave (100-200 mAmp, 1.5-2.5 Hz, in runs of 2-5 seconds) maximum in the parieto-occipital $(80 \%$, illustrated in figure) and frontal (20\%) regions present during $70 \%$ of record

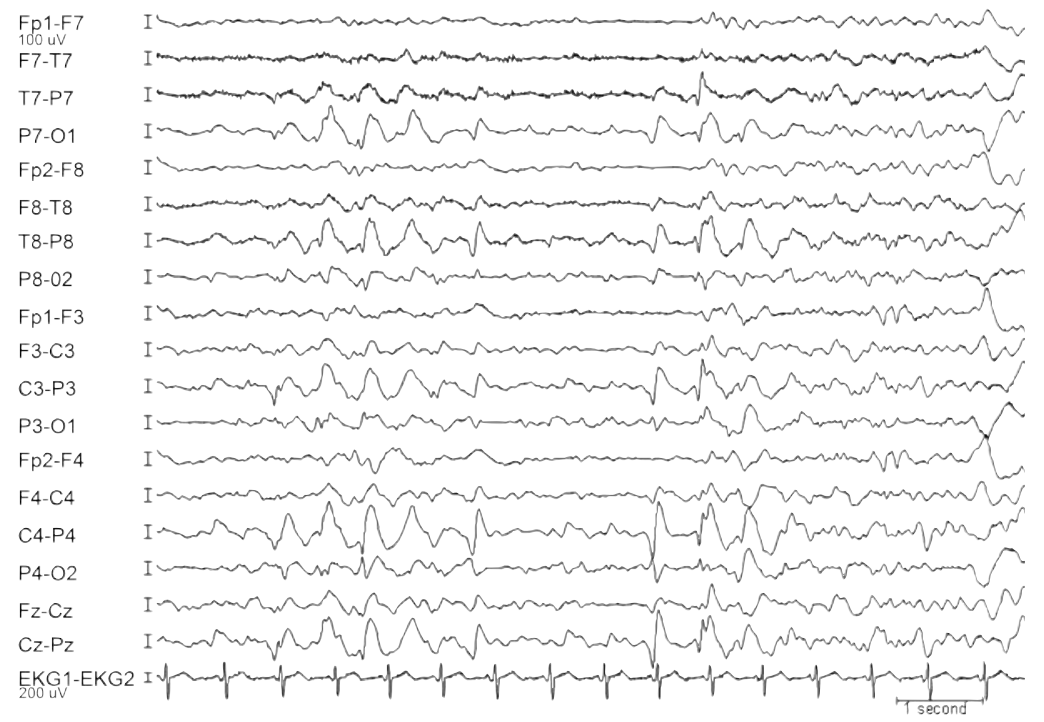

A 13-year-old girl with generalized tonic and grand mal seizures had brain MRI that revealed subcortical band heterotopia (SBH) (figure 1). Twenty-fourhour EEG showed pervasive generalized slow spike and wave pattern (figure 2). Blood DNA confirmed a mutation in the doublecortin $(D C X)$ gene. Interictal 18-fluoro-deoxy (FDG) PET showed reduced FDG uptake $(\sim 10 \%)$ in the cerebral cortex and intensely increased uptake $(\sim 20 \%)$ in the subcortical band (figure 1), suggesting epileptogenic subcortical band correlating with pervasive slow spike wave pattern on simultaneous EEG. Two PET reports ${ }^{1,2}$ showed similar or minor increased FDG uptake in the heterotopic band compared to the cerebral cortex.

Joanna Fong, MD, Guiyun Wu, MD, Elaine Wyllie, $M D$, Ajay Gupta, MD, Cleveland, $\mathrm{OH}$

Disclosure: The authors report no disclosures.

Address correspondence and reprint requests to Dr. Ajay Gupta, S-51, Epilepsy Center/Neurological Institute, Cleveland Clinic Foundation, Cleveland, OH 44195; guptaa1@ccf.org

1. Miura K, Watanabe K, Maeda N, et al. Magnetic resonance imaging and positron emission tomography of band heterotopia. Brain Dev 1993;15:288-290.

2. De Volder AG, Gadisseux JF, Michel CJ, et al. Brain glucose utilization in band heterotopia: synaptic activity of “double cortex”. Pediatr Neurol 1994;11:290-294. 


\section{Neurology}

\section{Interictal hypermetabolic subcortical band on brain FDG-PET in doublecortin mutation}

Joanna Fong, Guiyun Wu, Elaine Wyllie, et al. Neurology 2008;71;535

DOI 10.1212/01.wnl.0000325014.43936.6a

\section{This information is current as of August 11, 2008}

\section{Updated Information \& Services}

References

Subspecialty Collections

Permissions \& Licensing

Reprints including high resolution figures, can be found at: http://n.neurology.org/content/71/7/535.full

This article cites 2 articles, 0 of which you can access for free at: http://n.neurology.org/content/71/7/535.full\#ref-list-1

This article, along with others on similar topics, appears in the following collection(s):

All Epilepsy/Seizures

http://n.neurology.org/cgi/collection/all_epilepsy_seizures

EEG

http://n.neurology.org/cgi/collection/eeg_

EEG; see Epilepsy/Seizures

http://n.neurology.org/cgi/collection/eeg_see_epilepsy-seizures

PET

http://n.neurology.org/cgi/collection/pet

PET in epilepsy

http://n.neurology.org/cgi/collection/pet_in_epilepsy

Information about reproducing this article in parts (figures,tables) or in its entirety can be found online at:

http://www.neurology.org/about/about_the_journal\#permissions

Information about ordering reprints can be found online:

http://n.neurology.org/subscribers/advertise

Neurology ${ }^{\circledR}$ is the official journal of the American Academy of Neurology. Published continuously since 1951, it is now a weekly with 48 issues per year. Copyright . All rights reserved. Print ISSN: 0028-3878. Online ISSN: 1526-632X.

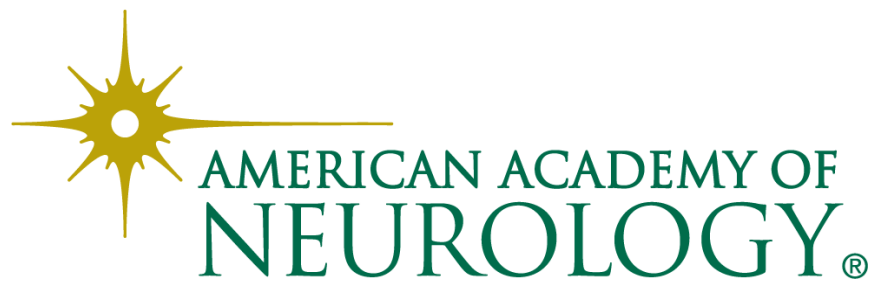

